\title{
PENGARUH EKSTRAK BIJI KABAU (Archidendron buballinum (Jack.) I.C.Nielsen) TERHADAP PENURUNAN KADAR GULA DARAH MENCIT PUTIH JANTAN DIABETES YANG DIINDUKSI ALOKSAN
}

\author{
The Effect Extract Kabau Seed (Arcidendron buballinum (Jack.)I.C.Nielsen) To \\ Decrease Blood Glucose Levels of White Male Mice Diabetic Induced Alloxan
}

\author{
Lilik Koernia Wahidah ${ }^{1}$, Nurma Suri ${ }^{2}$, Ratih Anggun Komalasari ${ }^{1}$ \\ ${ }^{1}$ Jurusan Farmasi -Universitas Tulang Bawang Lampung, ${ }^{2}$ Rumah Sakit Jiwa Lampung \\ Email : lilik.koernia82@gmail.com \\ 085357533853
}

\begin{abstract}
Kabau seeds (Arcidendron buballinum (Jack.)I.C.Nielsen) empirically are used by people in some area as an antidiabetes traditional medicine and diuretic herbal. The aim of this study was to determine the effect of extract Kabau sheeds to decrease glucose blood level in white male mice induced alloxan. The extraction was done by maseration using $70 \%$ ethanol. Antidiabetic test was done white male mice that induced intravenously by alloxan with $168 \mathrm{mg} / \mathrm{kgW}$ for 15 days. 25 mices were divided in to 5 treatment groups, group I, II, III were given extract of kabau seed with a dose 95, 190, $380 \mathrm{mg} / \mathrm{kgw}$, group IV as negative control given aquadest and group $V$ as positive control was given metformin $65 \mathrm{mg} / \mathrm{kgw}$. All groups were given treatment orally 3 times a day for 7 days. The decrease of glucose blood level was measured and observed in the first day, $15^{\text {th }}$ day and in the $22^{\text {th }}$ day data was analyzed by ANOVA method. The result of the characterization of simplisia kabau seeds moisture contents $0.23 \%$, ash content $2 \%$, and insoluble ash content in acid $2 \%$. The result phytochemicals screening that the extract have flavonoid, alcaloid, and saponin. The result of statistical tests showed that group I, II, and III didn't significantly diffrent from negative control, and significantly diffrent from the positive control to decrease glucose blood level of white male mice. From there, Dose $1(95 \mathrm{mg} / \mathrm{kgW})$ was the most to decrease blood level than others dose. However it was not significantly different with metformin.
\end{abstract}

Keywords : Kabau seed, Arcidendron buballinum, Diabetic

\begin{abstract}
Abstrak
Biji kabau (Archidendron buballinum (Jack.) I.C.Nielsen) secara empiris dimanfaatkan masyarakat dibeberapa daerah sebagai obat tradisional antidiabetes dan diuretik herbal. Penelitian ini bertujuan untuk melihat pengaruh ekstrak biji kabau terhadap penurunan kadar gula darah mencit putih jantan yang diinduksi aloksan. Biji kabau diekstraksi dengan cara maserasi menggunakan pelarut etanol $70 \%$. Uji antidiabetes dilakukan terhadap mencit jantan yang diinduksi aloksan secara intravena dengan dosis $168 \mathrm{mg} / \mathrm{kgBB}$ selama 15 hari. Sebanyak 25 ekor mencit dikelompokkan menjadi 5 kelompok, kelompok I, II dan III diberi ekstrak dengan dosis 95, 190, dan $380 \mathrm{mg} / \mathrm{kgBB}$, kelompok IV sebagai kontrol negatif diberi aquadest dan kelompok $V$ sebagai kontrol positif diberi metformin dosis $65 \mathrm{mg} / \mathrm{kgBB}$, kelima kelompok diberi perlakuan secara oral sebanyak 3 kali sehari selama 7 hari. Penurunan kadar gula darah diukur dan diamati pada hari ke 1 dan 15 dan hari ke 22 kemudian dianalisis dengan metode ANOVA. Hasil karakteristik simplisia terhadap kadar air $0,23 \%$, kadar abu $2 \%$ dan kadar abu tidak larut asam $2 \%$. Uji kualitatif fitokimia ekstrak menunjukkan adanya senyawa flavonoid, alkaloid dan saponin. Hasil analisis menunjukkan kelompok I,II dan III berbeda nyata terhadap kontrol negatif, dan berefek sama terhadap kontrol positif dalam
\end{abstract}


menurunkan kadar gula darah mencit putih jantan. Dari ketiga dosis tersebut dosis 1 $(95 \mathrm{mg} / \mathrm{kgBB})$ menunjukkan penurunan yang paling baik, namun dosis I,II dan III tidak berbeda nyata secara statistik terhadap metformin.

Kata kunci : Kabau, Archidendron buballinum, Diabetes

\section{PENDAHULUAN}

Penyebab kematian terbesar di dunia pada saat ini tidak lagi disebabkan oleh penyakit infeksi dan kurang gizi, melainkan penyakit degeneratif seperti kardiovaskular, kanker, dan salah satunya diabetes melitus. Hal ini disebabkan karena pola hidup masyarakat yang kurang sehat serta semakin canggihnya teknologi perkembangan zaman [1].

Diabetes Melitus (DM) merupakan suatu kelompok penyakit metabolik dengan karakteristik hiperglikemia yang terjadi karena kelainan sekresi insulin, kerja insulin atau kedua-duanya [2]. Diantara penyakit degeneratif, diabetes adalah salah satu di antara penyakit tidak menular yang akan meningkat jumlahnya di masa datang. Diabetes sudah menempati salah satu ancaman utama bagi kesehatan umat manusia pada abad 21 [1].

World Health Organization (WHO) membuat perkiraan bahwa pada tahun 2000 jumlah pengidap diabetes di atas umur 20 tahun berjumlah 150 juta orang dan dalam kurun waktu 25 tahun kemudian pada tahun 2025, jumlah itu akan membengkak menjadi 300 juta orang [1]. Berdasarkan data dari International Diabetes Federation (IDF) pada tahun 2011 jumlah penderita DM telah mencapai 366 juta orang di dunia dan diperkirakan akan meningkat menjai 552 juta pada tahun 2030 [3]. International Diabetes Federation (IDF) juga menyebutkan bahwa DM telah menjadi penyebab dari 4,6 juta kematian, disamping itu biaya kesehatan untuk DM telah mencapai 465 miliar USD [4]. Riset Kesehatan Dasar (RISKESDAS) Indonesia menyebutkan di Indonesia terdapat 12,19 juta penduduk $\geq 15$ tahun menderita diabetes, 3,7 juta diantaranya terdiagnosis dan 8,48 juta penduduk yang tidak terdiagnosis [5].

Melihat tendensi kenaikan kekerapan diabetes secara global yang telah dibicarakan terutama karena peningkatan kemakmuran suatu populasi, maka dengan demikian dapat dimengerti bila suatu saat atau lebih tepat lagi dalam kurun waktu 1 atau 2 dekade yang akan datang kekerapan DM di Indonesia akan meningkat dengan drastis. Hal ini dapat disebabkan oleh faktor demografi diantaranya jumlah penduduk meningkat, penduduk usia lanjut bertambah banyak, dan urbanisasi makin tidak terkendali, juga faktor lain seperti gaya hidup yang kebarat-baratan seperti pendapatan perkapita tinggi, restoran siap santap, teknologi canggih menimbulkan sedentary life atau kurang gerak badan, ataupun disebabkan karena faktor telah berkurangnya penyakit infeksi dan kurang gizi, juga meningkatnya pelayanan kesehatan hingga umur pasien diabetes menjadi lebih panjang [1].

Dalam penanggulangan diabetes pada saat ini biasanya diterapi dengan pemberian obatobat antidiabetes oral (ADO), atau dengan suntikan insulin bersama dengan pengaturan makan dan latihan jasmani (gaya hidup sehat) [6]. Namun pada penggunaan injeksi insulin pasien dominan mengeluh karena pemakaiannya yang sakit juga tidak praktis serta harga obat injeksi insulin yang relatif mahal. Obat antidiabetes oral seperti golongan sulfonilurea, biguanida dan acarbosa mungkin berguna untuk penderita yang alergi terhadap insulin atau yang tidak menggunakan suntikan insulin. Namun dalam penggunaan obat antidiabetes oral perlu dipahami pemilihan obat dan dosis yang diberikan agar didapatkan hasil terapi yang diinginkan dan resiko efek samping yang sering terjadi seperti kerusakan ginjal dalam jangka panjang, maka para ahli mengembangkan sistem pengobatan tradisional untuk DM yang relatif aman [7]. Salah satu terapi tradisional yang digunakan oleh masyarakat di Indonesia adalah terapi herbal. 
Jurnal Farmasi Lampung

Saat ini lebih dari 400 jenis tanaman telah digunakan sebagai pengobatan alternatif dan komplementer diabetes, walaupun hanya sedikit yang telah diteliti secara ilmiah [8]. Beberapa tanaman yang telah terbukti berkhasiat sebagai obat herbal antidiabetik diantaranya biji buah alpukat, daun kembang bulan, biji dan kulit jengkol dan masih banyak lagi. Menurut penelitian ekstrak biji buah alpukat pada dosis $600 \mathrm{mg} / \mathrm{kgBB}$ dapat menurunkan kadar gula darah tikus percobaan dan tidak memiliki perbedaan signifikan terhadap glibenklamid dosis 0,45 $\mathrm{mg} / \mathrm{kgBB}$ [9]. Sedangkan pada daun kembang bulan menurut penelitian fraksi petroleum eter daun kembang bulan dosis $100 \mathrm{mg} / \mathrm{kgBB}$ dapat menurunkan kadar gula darah hingga $41,19 \%$ [10]. Dan pada penelitian ekstrak etanol kulit biji jengkol dosis $1,5 \mathrm{~g} / \mathrm{kgBB}$ memiliki aktivitas yang sama dengan glibenklamid dosis 0,09 $\mathrm{mg} / 200 \mathrm{gBB}$ tikus percobaan [8]. Ekstrak biji jengkol diketahui dapat menurunkan kadar gula darah pada tikus percobaan dengan dosis $600 \mathrm{mg} / \mathrm{kgBB}$ yang tidak memberikan perbedaan yang signifikan terhadap metformin dosis $50 \mathrm{mg} / \mathrm{kgBB}$ [11].

Selain itu tanaman yang telah digunakan secara tradisional di beberapa daerah di Indonesia sebagai obat DM adalah biji kabau. Kabau belum banyak dikenal dan dimanfaatkan oleh masyarakat, tetapi keberadaannya di alam semakin berkurang. Secara alami kabau tumbuh liar di hutan primer dan sekunder dataran rendah, di Sumatera kabau dapat dijumpai di kebun karet rakyat dan perkarangan penduduk, Kabau memiliki banyak manfaat sehingga berpotensi untuk dikembangkan sebagai tanaman budi daya yang ditanam dengan sistem tumpang sari dalam sistem agoforestri karet [12].

Sejauh ini masyarakat mengenal kabau hanya sebagai lalapan atau pelengkap makanan, sedangkan kayunya digunakan sebagai bahan bangunan dan peralatan rumah tangga, namun dibeberapa daerah di Indonesia tumbuhan kabau telah digunakan sebagai obat tradisional seperti obat sakit perut dan demam seperti di daerah Sumatera Utara [13]. Secara empiris masyarakat Jambi memanfaatkan biji kabau sebagai obat
Vol. 7. No.1 Juni 2018

antidiabetes herbal. Bagian biji yang sudah masak dikeringkan dengan cara disangrai, kemudian ditumbuk halus. Biji kabau yang sudah dihaluskan selanjutnya dilarutkan dengan air dan diminum dua kali sehari [12]. Biji kabau diketahui memiliki kandungan senyawa flavonoid, alkaloid, dan saponin, sama dengan kandungan senyawa jengkol yang merupakan satu marga dengan kabau.

Dari latar belakang diatas peneliti tertarik terhadap manfaat biji kabau sebagai alternatif pengobatan herbal diabetes melitus. Oleh karena itu dipandang perlu dilakukan penelitian pengaruh ekstrak biji kabau terhadap penurunan gula darah mencit putih jantan diabetes yang diinduksi aloksan.

\section{METODE PENELITIAN}

\section{Alat dan Bahan}

Alat-alat yang digunakan adalah pipet volume, tabung reaksi, timbangan, kandang mencit, wadah makan dan minum mencit, kaca arloji, penjepit kayu, spatula, alat suntik $1 \mathrm{ml}$, sonde oral, gelas ukur, kertas saring, alumunium foil, kertas label, cawan porselen, kurs porselen, desikator, bunsen, gelas piala, labu ukur, erlenmeyer, blender (Philips), mortir stamper, penangas air, oven, glukosa-kit (nesco), rotary evaporator; mikropipet, cup sample blue, rak tabung, spidol permanen, tissue,spectrofotometri automatic (ABX PENTRA 400).

Bahan yang digunakan yaitu daun dan ranting kabau, biji kabau, PGA 3\%, etanol $70 \%$, aquadest, aloksan monohidrat, metformin, pakan mencit, larutan isotonis $\mathrm{NaCl} 0,9 \%$, sekam, asam sulfat $\left(\mathrm{H}_{2} \mathrm{SO}_{4}\right)$, asam klorida $(\mathrm{HCl})$, iodin (I), kalium iodida (KI), amoniak $\left(\mathrm{NH}_{3}\right)$, Glucose PAP CP Reagen. Hewan uji yang digunakan yaitu mencit putih jantan sebanyak 25 ekor berumur 2-3 bulan. 
Jurnal Farmasi Lampung

Prosedur Penelitian

\section{Pengambilan Bahan}

Bahan uji biji kabau diperoleh dari kebun LPTI Natar Lampung Selatan. Kondisi biji kabau yang diperoleh dipilih kualitas paling baik yaitu yang sudah tua dan biji berwarna coklat kehitaman serta memiliki bau menyengat.

\section{Determinasi Tanaman}

Biji Kabau ( $A$. buballinum) terlebih dahulu dideterminasi. Determinasi dilakukan di Laboratorium FMIPA Biologi Universitas Lampung.

\section{Pembuatan Simplisia Biji Kabau}

Bahan baku biji Kabau tua yang masih segar dikumpulkan, dibuang bagian yang tidak diperlukan (sortasi basah), dicuci bersih di bawah air mengalir, dan ditiriskan. Biji Kabau selanjutnya dikeringkan di bawah matahari hingga kering, benda-benda asing atau pengotoran-pengotoran lain yang masih tertinggal pada simplisia kering dibuang (sortasi kering), selanjutnya biji kabau yang sudah kering ditumbuk kasar dengan stemper dan alu, kemudian dihaluskan dengan blender lalu disimpan dalam wadah bersih. Dihasilkan 500 gr serbuk biji kabau (simplisia) dan selanjutnya dilakukan ekstraksi.

\section{Uji Karakteristik Simplisia Biji Kabau}

\section{Kadar Air Simplisia Biji Kabau}

Masukan lebih kurang $10 \mathrm{~g}$ ekstrak dan timbang seksama dalam cawan porselen yang telah ditara. Keringkan pada suhu $105^{\circ} \mathrm{C}$ selama 5 jam dan didinginkan dalam desikator lalu ditimbang. Lanjutkan pengeringan dan timbang pada jarak 1 jam sampai perbedaan antara 2 penimbangan berturut-turut tidak lebih dari 0,25\%.

\section{Kadar Abu Simplisia Biji Kabau}

Lebih Kurang $2 \mathrm{~g}$ sampai $3 \mathrm{~g}$ ekstrak yang telah digerus dan ditimbang seksama dimasukan kedalam krus porselen yang telah
Vol. 7. No.1 Juni 2018

ditara ratakan yaitu dengan cara kurs porselen yang kosong dipanaskan kemudian didinginkan dalam desikator lalu di timbang, perlakuan di ulang minimal tiga kali hingga di dapat selisih bobot kurs 0,002gr. Pijarkan perlahan-lahan hingga arang habis, kemudian dinginkan dalam desikator lalu timbang. Jika dengan cara ini arang tidak dapat dihilangkan, tambahkan air panas, saring melalui kertas saring bebas abu. Pijarkan sisa kertas dan kertas saring dalam krus yang sama. Masukan filtrat kedalam kurs, uapkan, pijarkan hingga bobot tetap, dinginkan dalam desikator lalu timbang. Hitung kadar abu terhadap bahan yang telah dikeringkan diudara. Selisih berat kadar abu total tidak boleh lebih dari 8,6\%.

\section{Kadar Abu Tidak Larut Asam}

Abu yang diperoleh pada penetapan kadar abu, didihkan dengan $25 \mathrm{ml}$ asam sulfat $\left(\mathrm{H}_{2} \mathrm{SO}_{4}\right)$ encer selama 5 menit, kumpulkan bagian yang tidak larut dalam asam, saring melalui krus kaca masir atau kertas saring bebas abu, cuci dengan air panas, pijarkan hingga bobot tetap, dinginkan dalam desikator lalu timbang. Hitung kadar abu larut dalam asam tidak lebih dari $0,9 \%$.

\section{Pembuatan Ekstrak Biji Kabau}

Pembuatan ekstrak biji Kabau dilakukan dengan metode maserasi. Serbuk simplisia sebanyak $300 \mathrm{~g}$ direndam etanol $70 \%$ hingga terendam sempurna dengan perbandingan simplisa dan pelarut 1:3 selama 24 jam, selanjutnya disaring menggunakan kertas saring hingga didapatkan maserat. Maserat tersebut kemudian dimasukan kedalam Erlenmeyer yang ditutup dengan alumunium foil. Kemudian dilakukan remaserasi terhadap ampas hingga pelarut jenuh atau tidak berubah warna, untuk mengetahui zat tersari sempurna maserat terakhir diambil sebanyak $5 \mathrm{ml}$ kemudian dimasukan kedalam gelas piala lalu dipanaskan, setelah tidak meninggalkan sisa/warna, maserasi dinyatakan selesai. Hasil maserat tersebut kemudian dievaporasi menggunakan rotary evaporator pada suhu $70{ }^{\circ} \mathrm{C}$ dan tekanan 1 atm hingga dihasilkan ekstrak kental. 


\section{JFL \\ Jurnal Farmasi Lampung Identifikasi Kimia Ekstrak Biji Kabau}

\section{Reaksi Identifikasi Alkaloid}

Ekstrak biji kabau sebanyak 0,5 g ditambahkan dengan $1 \mathrm{ml}$ asam klorida $(\mathrm{HCl})$ $2 \mathrm{~N}$ dan ditambahkan $9 \mathrm{ml}$ aquades, dipanaskan diatas penangas air selama 2 menit, dinginkan dan saring. Tiga tetes ekstrak dipindahkan pada kaca arloji dan ditambahkan preaksi wagner yaitu dibuat dengan cara $10 \mathrm{ml}$ aquades ditambahkan dengan $2,5 \mathrm{~g}$ iodin dan $2 \mathrm{~g}$ kalium iodida lalu dilarutkan dan diencerkan dengan aquades menjadi $200 \mathrm{ml}$ dalam labu ukur. Dilihat apakah terdapat endapan berwarna coklat.

\section{Reaksi Identifikasi Saponin}

Sebanyak 0,5 g ekstrak biji kabau ditambahkan $10 \mathrm{ml}$ aquades, didinginkan dan dikocok selama 10 detik. Adanya busa stabil selama 10 menit setinggi $1-10 \mathrm{~cm}$ menandakan adanya saponin.

\section{Reaksi Identifikasi Flavonoid}

Ekstrak biji kabau sebanyak $0,5 \mathrm{~g}$ dilarutkan didalam $10 \mathrm{ml}$ aquades, kemudian disaring menggunakan kertas saring sebanyak 2 tetes selanjutnya diuapkan diatas amoniak. Bila terbentuk warna kuning hingga jingga menunjukan adanya flavonoid.

\section{Perencanaan Dosis}

Dosis Ekstrak Biji Kabau pada percobaan dibuat 3 variasi dosis yaitu $95 \mathrm{mg} / \mathrm{kgBB}$, $190 \mathrm{mg} / \mathrm{kgBB}, 380 \mathrm{mg} / \mathrm{kgBB}$ mencit. Untuk menghitung konsentrasi pemberian sediaan uji pada mencit jantan digunakan rumus :

$$
\text { VAO }=\frac{\text { Dosis }\left(\frac{\mathrm{mg}}{\mathrm{kg}} \mathrm{BB}\right) \times \text { Berat Badan hewan }(\mathrm{kg})}{\text { KOnsentrasi }\left(\frac{\mathrm{mg}}{\mathrm{ml}}\right)}
$$

\section{Uji Aktivitas Antidiabetes}

Hewan uji yang digunakan dalam penelitian adalah mencit jantan, berumur 2- 3 bulan, dengan berat badan 30-35 gram. Hewan uji
Vol. 7. No.1 Juni 2018

dibagi menjadi 5 kelompok masing -masing 5 ekor sebagai berikut:

kelompok I : Hewan uji diberi perlakuan dengan ekstrak biji kabau konsentrasi $13 \mathrm{mg} / \mathrm{ml}$.

kelompok II : Hewan uji diberi perlakuan dengan ekstrak biji kabau konsentrasi $25,7 \mathrm{mg} / \mathrm{ml}$.

kelompok III :Hewan uji diberi perlakuan dengan ekstrak biji kabau dengan Konsentrasi 51,3 $\mathrm{mg} / \mathrm{ml}$.

kelompok IV : Kelompok kontrol hewan uji diberi perlakuan dengan aquades.

kelompok V : Kelompok kontrol positif, hewan uji diberi perlakuan dengan diberikan metformin konsentrasi $8,8 \mathrm{mg} / \mathrm{ml}$.

Perlakuan diberikan berulang selama 7 hari. Dua puluh lima ekor mencit dipuasakan (tidak makan tetapi tetap minum) selama 12 jam. Berat badan dan kadar glukosa darah puasa awal mencit diukur. Aloksan dosis 168 $\mathrm{mg} / \mathrm{kgBB}$ diberikan secara intravena pada hari ke-0 dan 2. Pada hari ke-10 dan 15 kadar glukosa darah puasa mencit juga diukur. Mencit yang telah diabetes (kadar glukosa darah $>150 \mathrm{mg} / \mathrm{dL}$ ) diberi perlakuan selama 7 hari, selama perlakuan mencit tetap diberi makan dan minum kemudian pada hari ke 22 glukosa darah di ukur dengan spektrofotometer. Sebelum digunakan spektrofotometer di kalibrasi terlebih dahulu. Kemudian sampel darah yang telah disentrifus diambil bagian serumnya dan dimasukan kedalam cup sample blue yang telah diberi identitas menggunakan spidol permanen sebanyak 300-400 $\mu$ l. masukan cup sample blue kedalam rak sample $A B X$ pentra. Dari main menu, pilih worklist, kemudian pilih patient, dan tekan tanda + lalu isi data dari patient demographis dan juga sample characteristic kemudian beri tanda checklist pada parameter glukosa setelah itu tekan ok. Kemudian tekan tombol start maka alat akan otomatis bekerja, untuk melihat hasil tekan validation.

\section{Rancangan Penelitian}

Penelitian ini merupakan penelitian analitik eksperimental dengan metode Pre and post 
Jurnal Farmasi Lampung

Test Control Group Design. Kelompokkelompok tersebut dianggap sama sebelum dilakukan perlakuan. Dengan rancangan ini, memungkinkan peneliti mengukur pengaruh perlakuan (intervensi) pada kelompok eksperimen dengan cara membandingkan kelompok tersebut dengan kelompok kontrol.

Pengambilan data dilakukan pada saat awal dan akhir penelitian setelah dilakukannya perlakuan dengan membandingkan hasil pada kelompok kontrol negatif dengan kelompok perlakuan. Hewan uji yang digunakan yaitu ekor mencit putih jantan dengan berat badan 30-35 gram, berumur 2-3 bulan yang dibagi menjadi 5 kelompok untuk digunakan sebagai penelitian.

\section{HASIL DAN PEMBAHASAN}

\section{Determinasi Tanaman}

Dalam memenuhi syarat parameter umum mutu simplisia suatu bahan kefarmasian dilakukan identifikasi tanaman untuk mengetahui kebenaran jenis tumbuhan yang digunakan, oleh karena itu dilakukan uji determinasi tanaman yang dilakukan di laboratorium botani Fakultas Matematika dan IImu Pengetahuan Alam Universitas Lampung. Dari hasil determinasi tersebut menunjukkan benar bahwa sampel yang digunakan yaitu biji kabau jenis Archidendron buballinum (Jack.) I.C.Nielsen (lampiran H). Agar kemurnian bahan bebas kontaminasi kimia dan biologis maka biji kabau diambil dari daerah yang jauh dari perindustrian ataupun pertambangan oleh karena itu sampel diambil di kebun LPTI kecamatan Natar Lampung Selatan. Biji kabau dipilih kualitas yang paling baik yaitu biji berwarna coklat kehitaman dan segar [18].

\section{Pembuatan Simplisia}

Pada pembuatan simplisia sampel yang digunakan yaitu biji kabau yang tua sebanyak 1000 gram. Kemudian dilakukan sortasi basah pada biji kabau, tahap ini bertujuan untuk membersihkan biji kabau dari pengotor lainnya seperti krikil-krikil, tanah dan kotoran lainnya yang dilakukan dengan cara pencucian menggunakan air mengalir.
Vol. 7. No.1 Juni 2018

Selanjutnya dilakukan pengeringan di bawah sinar matahari menggunakan wadah yang ditutup dengan kain hitam. Pengeringan bertujuan untuk mengurangi kadar air dan mengindari timbulnya jamur sehingga dapat disimpan dalam waktu lama, kain hitam digunakan agar panas terserap sempurna dan mencegah masuknya pengotor pada saat pengeringan. Setelah itu biji kabau kering dihaluskan dengan mengunakan blender dan didapat 500 gram serbuk simplisia. Selanjutnya simplisia disimpan di wadah yang tertutup rapat dan disimpan pada suhu kamar jika belum akan digunakan agar simplisia tetap dalam mutu yang terstandarisasi [21].

\section{Uji Parameter Non Spesifik}

Pengujian karakteristik simplisia yang dilakukan meliputi uji parameter non spesifik, batas minimal standar uji karakteristik simplisia yang akan dilakukan adalah tiga pengujian antara lain kadar air, kadar abu, dan kadar abu yang tidak larut dalam asam [21]. Hasil dari pengujian peremeter non spesifik ditunjukkan pada Table 1.

Tabel 1. Hasil Uji Parameter Non Spesifik

\begin{tabular}{|c|c|c|}
\hline Parameter & Hasil & Syarat \\
\hline A. Kadar Air & $0,23 \%$ & $\leq 10 \%$ \\
\hline B. Kadar Abu & $2 \%$ & $\leq 8,6 \%$ \\
\hline $\begin{array}{l}\text { C. Kadar Abu } \\
\text { Tidak } \\
\text { Larut } \\
\text { Asam }\end{array}$ & $2 \%$ & $\leq 2,9 \%$ \\
\hline
\end{tabular}

Pada tabel diatas dapat dilihat bahwa kadar air, kadar abu dan kadar abu tidak larut asam biji kabau telah memenuhi syarat standar umum simplisia tumbuhan obat. Kadar air simplisia merupakan salah satu parameter non spesifik yang tujuannya memberikan batasan minimal (rentang) tentang besarnya kandungan air pada bahan. Pada penentuan parameter kadar air pada simplisa biji kabau didapat kadar air sebesar 0,23\% menunjukkan bahwa kadar susut pada simplisia biji kabau dalam batas normal tidak melebihi dari nilai standar yang telah ditetapkan oleh parameter standar umum ekstrak tumbuhan obat yaitu $<10 \%$ [21]. 
Kadar abu ekstrak biji kabau memenuhi syarat standar yaitu $2 \%$ kurang dari $8,6 \%$. Pada penentuan parameter non spesifik dilakukan juga uji kadar abu yang bertujuan untuk memberikan gambaran kandungan mineral internal dan eksternal yang berasal dari awal sampai terbentuknya simplisia dan menentukan jumlah pengotor pada saat proses pembuatan simplisia. Hasil yang diperoleh adalah 2\% menunjukkan bahwa kadar abu pada simplisa biji kabau dalam batas normal tidak melebihi dari nilai standar yang telah di tetapkan yaitu 8,65\% [21].

Kadar abu tidak larut asam ekstrak biji kabau memenuhi standar syarat yaitu $2 \%$ tidak melebihi nilai syarat standar yaitu 2,9\%. Pada pengujian kadar abu tidak larut asam bertujuan untuk menentukan tingkat pengotoran oleh pasir atau pengotoran lainnya. hasil yang diperoleh adalah $2 \%$ menunjukkan bahwa kadar abu tidak larut asam pada simplisa biji kabau memenuhi nilai standar yang telah ditetapkan yaitu kurang dari 2,9\%. Nilai kadar abu tidak larut asam yang tinggi menunjukkan adanya pengotor dalam simplisa [21].

\section{Ekstraksi}

Setelah didapat simplisia selanjutnya dilakukan ekstraksi. Simplisia biji kabau sebanyak $300 \mathrm{~g}$ diekstraksi dengan cara maserasi menggunakan pelarut etanol $70 \%$ sampai simplisia terendam sempurna dengan perbandingan simplisia dan pelarut 1:3 yang dilakukan didalam wadah berwarna gelap. Maserasi dipilih karena pelaksanaannya yang sederhana selain sederhana maserasi merupakan metode ekstraksi dengan cara dingin, metode ini bermanfaat untuk senyawa-senyawa yang tidak tahan pada pemanasan tinggi. Pelarut etanol $70 \%$ digunakan karena etanol merupakan pelarut yang bersifat universal sehingga dapat menarik zat atif yang bersifat polar, semi polar dan non polar [27]. Zat aktif yang diduga memiliki aktivitas antidiabetes adalah zat aktif yang bersifat polar diantaranya yaitu flavonoid dan saponin. Dalam penelitian ini sampel yang digunakan adalah sampel kering, sehingga dibutuhkan etanol yang mengandung kadar air tinggi sekitar $30 \%$, untuk membasahi sampel sehingga sel-selnya mengembang dan pelarut lebih mudah berpenetrasi untuk melarutkan senyawa yang terkandung di dalam simplisia [27]. Kemudian dilakukan remaserasi dengan jumlah pelarut yang sama hingga pelarut tidak berubah warna lagi. Maserasi dilakukan selama 5 hari.

Maserat yang dihasilkan kemudian dipekatkan dengan menggunakan rotary evaporator pada suhu $50^{\circ} \mathrm{C}$. rotary evaporator menggunakan bantuan pompa vakum akan menurunkan tekanan uap pelarut sehingga pelarut akan menguap di bawah titik didih normalnya. Tujuannya adalah agar komponen fitokimia yang terdapat dalam ekstrak tidak mengalami kerusakan akibat pemanasan yang berlebihan [27]. Adanya tekanan yang diberikan oleh pompa vakum mengakibatkan pelarut menguap dari campuran kemudian terkondensasi dan masuk dalam labu penampung. Kemudian diperoleh ekstrak cair $100 \mathrm{ml}$ berwarna coklat kehitaman sehingga rendemen yang dperoleh sebanyak 0,33. Randemen merupakan perbandingan antara bobot ekstrak yang diperoleh dengan bobot simplisia awal yang digunakan untuk perhitungan penentuan dosis.

\section{Penapisan Fitokimia}

Setelah ekstrak biji kabau diperoleh dilakukan uji fitokimia ekstrak biji kabau yang bertujuan untuk memastikan senyawa yang terkandung dalam ekstrak biji kabau. Uji ini merupakan uji kualitatif yang bertujuan untuk menunjukkan keberadaan senyawa tertentu ketika direaksikan dengan senyawa lain. Uji fitokimia yang dilakukan antara lain flavonoid, alkoloid, dan saponin. Berikut hasil uji fitokimia:

Tabel 2. Hasil Uji Fitokimia

\begin{tabular}{c|c|c|c}
\hline No & $\begin{array}{c}\text { Senyawa } \\
\text { kimia }\end{array}$ & Hasil & Keterangan \\
\hline 1 & Flavonoid & + & $\begin{array}{c}\text { Berubah warna } \\
\text { kuning atau jingga }\end{array}$ \\
\hline 2 & Saponin & + & Busa yang stabil \\
\hline 3 & Alkoloid & + & Endapan coklat \\
\hline
\end{tabular}

Keterangan :

1.Uji flavonoid $(+)$ di tandai dengan perubahan warna kuning. 
2.Uji saponin (+) di tandai dengan terbentuknya busa yang tahan selama 10 menit.

3.Uji alkoloid (+) di tandai dengan terbentuknya endapan coklat.

Berdasarkan pada tabel hasil penelitian di atas menunjukkan bahwa flavonoid positif terkandung dalam ekstrak biji kabau dengan ditandai dengan perubahan warna kuning pada saat diuapkan dengan amoniak. Flavonoid merupakan salah satu kelompok senyawa metabolit sekunder yang paling banyak ditemukan di dalam jaringan tanaman yang merupakan salah satu dalam golongan senyawa phenolik dengan struktur kimia $\mathrm{C6}_{6}$ $\mathrm{C}_{3}-\mathrm{C}_{6}$. Flavonoid terutama quercetin memiliki mekanisme menghambat transporter glukosa 2 mukosa usus sehingga dapat menurunkan absorbsi glukosa. Hal ini menyebabkan pengurangan penyerapan glukosa dan fruktosa dari usus sehingga kadar glukosa darah turun. Transporter glukosa 2 diduga merupakan transporter mayor glukosa di usus pada kondisi normal [28]. Selain itu flavonoid turunan flavon seperti gossypetin (hexahidroxyflavo)-3glucosida yang bersifat antioksidan, yang dapat menghambat kerusakan sel $\beta$ pada pulau langerhans pankreas yang menghasilkan insulin dan merangsang pelepasan insulin pada sel $\beta$ pankreas untuk disekresikan ke dalam darah, dan flavonoid juga dapat mengembalikan sensitivitas reseptor insulin pada sel [29]. Hal ini menunjukkan bahwa mekanisme flavonoid sinergis dengan mekanisme dari metformin.

Kemudian saponin menunjukkan hasil positif terkandung dalam ekstrak biji kabau yang di tandai dengan timbulnya buih/busa yang tahan selama 10 menit pada saat ekstrak biji kabau ditambahkan dengan aquades kemudian dikocok. Timbulnya busa menunjukkan adanya glikosida yang mempunyai kemampuan membentuk buih dalam air yang terhidrolisis menjadi glukosa dan senyawa lainnya. Saponin merupakan senyawa aktif permukaan yang kuat dimana mengeluarkan busa bila dikocok dalam air dan pada konsentrasi yang rendah sering menyebabkan hemolisis sel darah merah selain itu saponin juga berpengaruh terhadap absorbsi suatu zat aktif secara farmakologi dan juga merangsang absorbsi diuretika yang menyebabkan perangsangan terhadap ginjal agar lebih aktif [30].

Ekstrak biji kabau menunjukkan hasil positif mengandung alkoloid ditandai dengan adanya endapan berwarna coklat ketika direaksikan dengan pereaksi wagner. Iodin bereaksi dengan ion $\mathrm{I}^{-}$dari kalium iodide menghasilkan ion $\mathrm{I}^{3-}$ yang berwarna coklat. Pada uji wagner, ion logam $\mathrm{K}+$ akan membentuk ikatan kovalen koordinat dengan nitrogen pada alkoloid membentuk kompleks kalium-alkoloid yang mengendap [27]. Alkaloid memiliki kecenderungan melepaskan insulin dari sel beta pankreas dan memiliki kemampuan untuk melindungi sel beta pankreas dari kerusakan pankreas akibat induksi aloksan pada hewan uji [10]. Hasil yang di dapat pada penapisan fitokomia biji kabau ini sama dengan penelitian yang dilakukan sebelumnya yang menunjukkan adanya flavonoid, saponin dan alkaloid pada biji kabau [15].

\section{Uji Antidiabetes}

Setelah dipastikan ekstrak biji kabau memiliki kandungan senyawa yang diduga memiliki efek antidiabetes selanjutnya dilakukan uji antidiabetes. Pengaruh ekstrak biji kabau dapat diketahui dengan melihat selisih kadar gula darah mencit setelah pemberian aloksan selama 15 hari dan kadar gula darah setelah mencit diabetes diberi ekstrak selama 7 hari. Selisih penurunan kadar gula darah tersebut menunjukan adanya pengaruh antidiabetes pada ekstrak biji kabau. Pengujian antidiabetes pada penelitian ini menggunakan hewan uji mencit putih jantan dengan bobot 30-35 g dengan volume darah $7 \%$ berat badan yaitu kurang lebih $2,1-2,5$ $\mathrm{ml}$ dan digunakan metode pre and post test control group design. Dimana kadar gula darah awal mencit diukur menggunakan glucostrip tester pada hari pertama kemudian dicatat, mencit dipuasakan selama 12 jam.

Selanjutnya mencit setiap kelompok diinduksi aloksan monohidrat (lampiran $G$ ) yang bekerja merusak sel $\beta$ pankreas dengan dosis $168 \mathrm{mg} / \mathrm{kgBB}$ hingga mencit dinyatakan diabetes yaitu pada hari ke 15 dimana kadar gula darah $>150 \mathrm{mg} / \mathrm{dl}$ dan bobot tubuh mencit turun menjadi $25-30 \mathrm{~g}$ 
Jurnal Farmasi Lampung

dan volume darah kurang lebih 1,75-2,1 ml. Pada pengujian antidiabetes ini menggunakan PGA 3\% yang berfungsi sebagai pensuspensi larutan stock yang bertujuan untuk menghambat pertumbuhan mikroorganisme pada larutan yang menggunaka pelarut air.

Kontrol positif yang digunakan sebagai pembanding yaitu metformin dengan dosis $65 \mathrm{mg} / \mathrm{kgBB}$, metformin dipilih karena mekanisme kerja golongan biguanida yaitu menurunkan glukosa darah melalui pengaruhnya terhadap kerja insulin pada tingkat selular, distal reseptor insulin, dan menurunkan glukosa hati, metformin juga meningkatkan pemakaian glukosa oleh sel usus sehingga menurunkan glukosa di usus setelah makan [23] dan aquades digunakan sebagai kontrol negatif. Ekstrak biji kabau menggunakan 3 varian dosis yaitu 95 $\mathrm{mg} / \mathrm{kgBB}, 190 \mathrm{mg} / \mathrm{kgBB}$, dan $380 \mathrm{mg} / \mathrm{kgBB}$. Ekstrak biji kabau diberikan selama 7 hari yaitu pada hari ke 16 hingga hari ke 22 . Kemudian pada hari ke 23 dilakukan euthanasia pada mencit dengan cara mengambil darah mencit secara intrakardia untuk selanjutnya dilakukan analisis kadar gula darah mencit tersebut secara spektrofotometri automatic. Pada analisis menggunakan spektrofotometri automatic dibutuhkan sampel darah minimal $1,2 \mathrm{ml}$ untuk sentrifus yang bertujuan memisahkan plasma darah dan serum kemudian serum diambil sebanyak $0,33 \mathrm{ml}$ dimasukkan kedalam cup sample blue dan dilakukan pengukuran dengan menggunakan reagen Glucose PAP CP . berikut Tabel rata-rata kadar gula darah mencit pada hari ke 1,15 dan 22 tabel 3.

Tabel 3 Rata-Rata Kadar Gula Darah Mencit $(\mathrm{mg} / \mathrm{dl})$

\begin{tabular}{c|c|c|c}
\hline \multirow{2}{*}{ Perlakuan } & \multicolumn{3}{|c}{$\begin{array}{c}\text { Rata-rata Kadar Gula } \\
\text { Darah Mencit (mg/dl) } \\
\text { Pada Hari ke }\end{array}$} \\
\cline { 2 - 4 } & $\mathbf{1}$ & $\mathbf{1 5}$ & $\mathbf{2 2}$ \\
\hline K- & 52 & 215,2 & 211.274 \\
\hline K+ & 49,4 & 206,4 & 92.834 \\
\hline P1 & 47,8 & 223,4 & 95.510 \\
\hline P2 & 52,5 & 207,8 & 82.536 \\
\hline P3 & 41,2 & 228 & 105.666 \\
\hline
\end{tabular}

Keterangan
Vol. 7. No.1 Juni 2018

K- : Aquadest

$\mathrm{K}+$ : Metformin dosis $65 \mathrm{mg} / \mathrm{kgBB}$

P1 : Ekstrak biji kabau dosis $95 \mathrm{mg} / \mathrm{kgBB}$

P2 : Ekstrak biji kabau dosis $190 \mathrm{mg} / \mathrm{kgBB}$

P3 : Ekstrak biji kabau dosis $380 \mathrm{mg} / \mathrm{kgBB}$

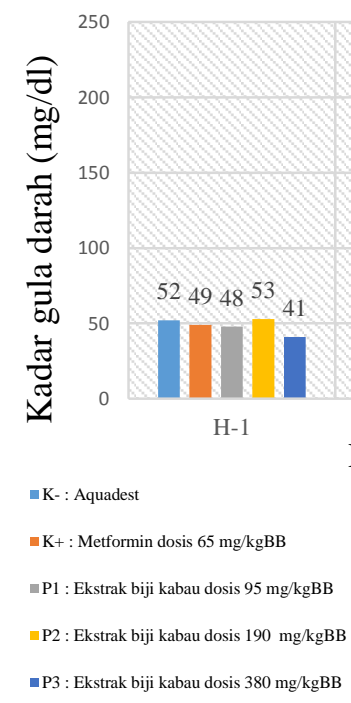

Gambar 1 Rata-Rata Penurunan Kadar Gula Darah Mencit

Dalam penelitian ini telah dilakukan uji antidiabetes ekstrak biji kabau sebagai kelompok eksperimen. Berdasarkan hasil pengujian dapat di lihat pada (Gambar 1). Penurunan kadar gula darah tertinggi di tunjukan pada kelompok perlakuan 2 yaitu dengan ekstrak biji kabau dosis $190 \mathrm{mg} / \mathrm{kgBB}$ dengan rata-rata kadar gula darah akhir 82,5 $\mathrm{mg} / \mathrm{dl}$ yang menunjukan penurunan lebih baik dibanding dengan kontrol positif metformin dosis $65 \mathrm{mg} / \mathrm{kgBB}$ yang memiliki rata-rata kadar gula darah akhir 92,8 $\mathrm{mg} / \mathrm{dl}$. Sedangkan pada perlakuan 1 dengan pemberian dosis ekstrak biji kabau 95 $\mathrm{mg} / \mathrm{kgBB}$ dan perlakuan 3 dengan pemberian ekstrak biji kabau dosis $380 \mathrm{mg} / \mathrm{kgBB}$ memiliki rata-rata kadar gula darah akhir sebesar 95,5 mg/dl dan 105,6 mg/dl yang memiliki nilai rata-rata akhir lebih tinggi dari kontrol positif metformin. Pada perlakuan 2 menunjukan hasil yang efektif sebagai antidiabetes bahkan lebih baik dari kontrol positif, namun pada perlakuan 3 dengan dosis ekstrak yang lebih tinggi dari perlakuan 2 tidak menunjukan hasil akhir yang lebih baik dibanding dengan perlakuan 2 yang 
Jurnal Farmasi Lampung

memiliki dosis lebih rendah hal tersebut dapat dipengaruhi karena nilai kadar gula darah awal setiap hewan uji berbeda dan pengelompokan hewan iji dilakukan secara random sehingga dihasilkan nilai rata-rata yang berbeda setiap kelompoknya, namun hal tersebut secara statistika tidak menimbulkan perbedaan bermakna.

\section{Analisis Data}

Dari hasil yang didapat dilakukan analisis data dengan metode ANOVA dan uji lanjut BNT untuk untuk mengetahui kelompok mana sajakah yang memiliki perbedaan bermakna. Berikut table hasil analisis Tabel 4.

Tabel 4 Kesimpulan perbedaan setiap kelompok perlakuan

\begin{tabular}{c|c|c}
\hline Kelompok & Rerata & BNT 5\% \\
\hline K- & 211,274 & B \\
\hline K+ & 92,834 & A \\
\hline P1 & 95,510 & A \\
\hline P2 & 82,536 & A \\
\hline P3 & 105,666 & A \\
\hline
\end{tabular}

Keterangan :

$\mathrm{K}-$ : Aquadest

$\mathrm{K}+$ : Metformin dosis $65 \mathrm{mg} / \mathrm{kgBB}$

P1 : Ekstrak biji kabau dosis $95 \mathrm{mg} / \mathrm{kgBB}$

P2 : Ekstrak biji kabau dosis $190 \mathrm{mg} / \mathrm{kgBB}$

P3 : Ekstrak biji kabau dosis 380 mg/kgBB

Berdasarkan hasil BNT 5\% kontrol negatif berbeda nyata dengan kelompok dosis 1 , dosis 2 dan dosis 3 berbeda nyata dengan control negatif $(P<0,05)$ artinya dosis 1 , dosis 2 dan dosis 3 memiliki efek sebagai antidiabetes,, kelompok kontrol negatif berbeda nyata dengan kelompok kontrol positif $(P<0,05)$, kelompok dosis 1 tidak berbeda nyata dengan dosis $2 \quad(P>0,05)$ artinya dosis 1 memiliki efek yang sama dengan kelompok dosis 2 sebagai antidiabetes, dan kelompok dosis 2 juga sama dengan kelompok dosis $3 \quad(\mathrm{P}<0,05)$ artinya kelompok dosis 2 sama dengan kelompok dosis 3 sebagai antidiabetes, kelompok dosis 1 juga sama dengan kelompok dosis $3 \quad(\mathrm{P}<0,05)$ yang artinya
Vol. 7. No.1 Juni 2018

kelompok dosis 1 sama dengan kelompok dosis 3 sebagai antidiabetes.

Dari penelitian yang telah dilakukan diketahui bahwa ekstrak biji kabau memiliki kandungan senyawa flavonoid, saponin dan alkaloid. Senyawa yang diduga dapat menurunkan kadar gula darah yaitu flavonoid dan alkaloid, namun perlu dilakukan penelitian lebih lanjut untuk mengetahui senyawa mana yang berpengaruh terhadap penurunan kadar gula darah. Kemudian uji antidiabetes menunjukkan bahwa terdapat pengaruh ekstrak biji kabau terhadap penurunan kadar gula darah mencit putih jantan diabetes yang diinduksi aloksan, sehingga ekstrak biji kabau dapat digunakan sebagai obat tradisional herbal antidiabetes dengan dosis optimal $190 \mathrm{mg} / \mathrm{kgBB}$ mencit atau setara dengan $21 \mathrm{mg} / \mathrm{kgBB}$ manusia. Namun perlu dilakukan uji lebih lanjut terhadap marker uji yang lebih signifikan juga efek samping dan toksisitas dari ekstrak biji kabau pada pemakaian jangka panjang.

\section{KESIMPULAN DAN SARAN}

\section{Kesimpulan}

Berdasarkan hasil pengujian pengaruh ekstrak biji kabau terhadap penurunan kadar gula darah mencit putih jantan diabetes yang diinduksi aloksan dapat disimpulkan bahwa ekstrak etanol biji kabau mengandung senyawa flavonoid, alkaloid dan saponin. Ekstrak biji kabau (Archidendron bubalinum) berpengaruh terhadap penurunan kadar gula darah mencit putih jantan diabetes yang diinduksi aloksan.

Ekstrak biji kabau dosis $95 \mathrm{mg} / \mathrm{kgBB}$, dosis $190 \mathrm{mg} / \mathrm{kgBB}$, dan dosis $380 \mathrm{mg} / \mathrm{kgBB}$ memiliki pengaruh terhadap penurunan kadar gula darah mencit putih jantan diabetes yang diinduksi aloksan. Ekstrak biji kabau dosis $95 \mathrm{mg} / \mathrm{kgBB}$ memiliki efek penurunan lebih baik dibanding dengan pembanding metformin $65 \mathrm{mg} / \mathrm{kgBB}$. Namun tidak ada perbedaan signifikan antara dosis I,II,III dan kontrol positif secara statistik.

\section{Saran}

1. Sebaiknya dilakukan pengujian lebih lanjut terhadap toksisitas ekstrak biji kabau. 
Jurnal Farmasi Lampung

2. Sebaiknya dilakukan pengujian lebih lanjut untuk mengetahui senyawa spesifik yang memiliki efek antidiabetes.

3. Perlu dilakukan uji antidiabetes lebih lanjut terhadap marker yang lain.

\section{DAFTAR PUSTAKA}

[1] Suyono selamet. Diabetes Melitus di Indonesia. In: Siti S, Idrus A, Aru W, Marcellus S, Bambang S, Ari $F$ et al, editor. 2014. Ilmu Penyakit Dalam. VI. Jakarta: Interna Publishing; p. 2317-24.

[2] Purnamasari D. Diagnosis dan Klasifikasi Diabetes Melitus. In: Siti S, Idrus A, Aru W, Marcellus S, Bambang S, Ari $F$ et al, editor. 2014. Ilmu Penyakit Dalam. VI. Jakarta: Interna Publishing; p. 2325-9.

[3] International Diabetes Federation. One Adult In Ten Will Have Diabetes by 2030. 2011; Available from: http//www.idf.org/media-events/pressrealese/2011/diabetes-atlas-5th-edition

[4] Soegondo S. Farmakoterapi Pada Pengendalian Glikemia Diabetes Melitus. In: Siti S, Idrus A, Aru W, Marcellus S, Bambang S, Ari $\mathrm{F}$ et al, editor.2014. IImu Penyakit Dalam. VI. Jakarta: Interna Publishing; p. 2330-7.

[5] Badan Penelitian dan Pengembangan. Riset Kesehatan Dasar. Indonesia; 2013.

[6] Tjokoprawiro A. Terapi non Farmakologi Pada Diabetes Mellitus. In: Siti S, Idrus A, Aru W, Marcellus S, Bambang S, Ari F et al, editor. 2014 Ilmu Penyakit Dalam. VI. Jakarta: Interna Publishing. p. $2338-48$.

[7] Ganiswara S. 1995. Farmakologi dan Terapi. 4th ed. Jakarta: Bagian Farmakologi Fakultas Kedokteran Universitas Indonesip. p. 467-481

[8] Syafnir S. 2014. Uji Aktivitas Ekstrak Etanol Kulit Jengkol Archidendron pauciflorium. Uji Akt Ekstrak Etanol Kulit
Vol. 7. No.1 Juni 2018

Jengkol Arch pauciflorium.

[9] Oktaria Y. 2013. Uji Aktivitas Antidiabetes Ekstrak Etanol Biji Alpukat Terhadap Tikus Galur Wistar Yang diinduksi Aloksan.

[10] Anwar K et al. 2016. Perbandingan Efek Ekstrak Etanol, Fraksi N-Butaol, dan Fraksi Petrolium Eter Daun Kembang Bulan Terhadap Penurunan Kadar Glukosa Darah Mencit Jantan yang diinduksi Aloksap. p. 3:80-8.

[11] Faridah. 2017. Pengaruh Pemberian Ekstrak Etanol 96\% Biji Jengkol Terhadap Hispatologi Jaringan Ginjal Serta Peningkatan Kadar Ureum Keratinin Tikus Putih Jantan Galur Sprague Dawley.

[12] Komariah Dewi. 2016. Keanekaragaman dan Pemanfaatan Kabau dan Kerabatkerabatnya. Institut Pertanian Bogor.

[13] Silalahi M. 2015. Kajian Ekologi Tumbuhan Obat di Afroforest Desa Surung Mersada Kabupaten Phakpak Bharat Sumatera Utara. p.19:89-94.

[14] Sabita D. 1986. Komposisi Zat Bahan Makanan Beberapa Daerah di Indonesia. Indonesia.

[15] Liliwirians, Musa NLW, Zain WZWM, Kassim J KS. 2011. Premilinary Studies on Phytocemical Screening of Ulam and Fruit From Malaysia. p. 85-8.

[16] Lenny S. 2006. Senyawa Flavonoida, Fenilpropanoida dan Alkaloida. karya IIm.

[17] Okky Meidiana Prameswari1 SBW. 2014. Uji Efek Ekstrak Air Pandan Wangi Terhadap Penurunan Kadar Glukosa Darah dan Hispatologi Tikus Diabetes Melitus. J Pangan dan Agroindustri. p. 2:16-27.

[18] Arif Rachman, Sri Wadatun IY. 1995. Isolasi Dan Identifikasi Senyawa Saponin Ekstrak Metanol Daun Binahong ( Anredera cordifolia (Ten.) 
Jurnal Farmasi Lampung Steenis).

[19] Ditjen POM. Farmakope Indonesia IV. Jakarta: Depertemen Kesehatan RI.

[20] Depertemen Kesehatan RI. 2013. Pedoman Teknologi Berbasis Ekstrak. Jakarta.

[21] Depertemen Kesehatan RI. 2000. DP. Parameter Standar Umum Ekstrak Tumbuhan Obat. Jakarta: Depertemen Kesehatan RI.

[22] Manaf A. 2014. Insulin, Mekanisme Sekresi dan Metabolisme. In: Siti S, Idrus A, Aru W, Marcellus S, Bambang $S$, Ari $F$ et al, editor. Ilmu Penyakit Dalam. VI. Jakarta: Interna Publishing. p. 2352-6.

[23] Tjay TH RK. 2001. Obat-obat Penting. V. p. 639-713.

[24] Irdalisa et al. 2015. Pengaruh Pemberian Glukosa Darah Pada Tikus Setelah Penyuntikan Aloksan Sebagai Hewan Model Hiperglikemik.Skripsi.

[25] Nasrudin et al. 2014. Pengaruh Pemberian Ekstak Biji Jengkol Terhadap Kadar HDL Tikus Putih Jantan Galur Sprague Dawley yang diinduksi Aloksan. Skripsi.

[26] Akbar Budhi. 2010. Tumbuhan Dengan Kandungan Senyawa Aktif yang Berfungsi Sebagai Bahan Antifertilitas. 1st ed. Jakarta. p. 6-7

[27] Luthpi widya putri, Umi yuniarni siti hazar. 2015. Uji Efek Antihiperglikemia Kombinasi Ekstrak Etanol Daun Alpukat dan Biji Alpukat (Percea americana Mill) Terhadap Mencit Jantan yang diinduksi Aloksan. ISSN 2460-6472.

[28] Rizky Bayu Ajie. 2014. White Dragon Fruit (Hylocereus undatus) Potential as Diabetic Melitus Treatment. J Major.

[29] H Atiqoh. 2017. Uji Antidiabetik Infusa Kelopak Bunga Rosella (Hibicus sabdariffa Linn.) Pada Tikus Putih
Vol. 7. No.1 Juni 2018

Jantan Galur Wistar yang diinduksi Glukosa. Skripsi.

[30] Kristianti PA. 2007. Isolasi dan Identifikasi glikosida saponin pada Herba Krokot. Skripsi. 


JFL
Jurnal Farmasi Lampung $\quad$ Vol. 7. No.1 Juni 2018

